\title{
PENGARUH PENYIMPANAN SAMPAI ENAM BULAN MENGGUNAKAN BUBUK DAN TANPA BUBUK LADA TERHADAP MUTU LIMABELAS LOT BENIH KEDELAI (Glycine $\max$ L.)
}

\author{
The Effect of Storage until Six months using powder and without on Quality of \\ Fifteen Lots of Soybean Seeds (Glycine max L.) \\ Ayu Kurniati ${ }^{1)}$, Agustiansyah ${ }^{1 *}$, Yayuk Nurmiaty $^{1)}$, Ermawati $^{1)}$, \\ 1) Jurusan Agronomi dan Hortikultura, Fakultas Pertanian Universitas Lampung \\ Jl. Prof. Soemantri Brodjonegoro No 1 Gedung Meneng, Bandar Lampung 35145 \\ *Email korespondensi: agustiansyah.1972@fp.unila.ac.id
}

\begin{abstract}
ABSTRAK
Penelitian ini bertujuan untuk mengetahui mutu benih terbaik dari limabelas lot benih kedelai yang disimpan sampai enam bulan menggunakan bubuk lada dan tanpa menggunakan bubuk lada. Perlakuan diterapkan dalam Rancangan Acak Lengkap (RAL) yang diulang tiga kali. Kombinasi perlakuan yang berasal dari tiga varietas yaitu varietas Anjasmoro, varietas Gerobogan, dan varietas Burangrang dikombinasikan dengan 5 dosis pupuk SP-36 yaitu 0, 100, 150, 200, dan $250 \mathrm{~kg} / \mathrm{ha}$. Percobaan terdiri dari dua percobaan. Percobaan 1, kelima belas lot benih disimpan tanpa pemberian bubuk lada. Percobaan 2, kelima belas lot benih diberi bubuk lada dalam penyimpananya. Penyimpanan pada suhu ruang berkisar antara $28-30^{\circ} \mathrm{C}$ di Laboratorium Benih dan Pemuliaan Tanaman, Fakultas Pertanian Universitas Lampung pada bulan Oktober 2017 sampai dengan April 2018. Hasil penelitian menunjukkan bahwa kombinasi perlakuan varietas Burangrang dengan dosis pupuk SP-36 $250 \mathrm{~kg} / \mathrm{ha}$ yang disimpan tanpa bubuk lada atau diberi bubuk lada mampu mempertahankan mutunya lebih tinggi dibandingkan dengan kombinasi perlakuan lainnya setelah disimpan sampai enam bulan.
\end{abstract}

Kata kunci: kedelai, varietas, pupuk, mutu, bubuk lada

\begin{abstract}
This study aims to determine the best seed quality from fifteen lots of soybean seeds that are stored for up to six months using pepper powder and without using pepper powder. The treatment was applied in a Completely Randomized Design (CRD) which was repeated three times. The combination of treatments derived from three varieties, namely Anjasmoro, Gerobogan, and Burangrang combined with 5 SP-36 fertilizer doses, namely 0, 100, 150,200, and $250 \mathrm{~kg} / \mathrm{ha}$. The experiment consisted of two experiments. Experiment 1, the fifteen lots of seeds were stored without pepper powder. Experiment 2, the fifteen lots of seeds were ground with pepper in their storage. Storage at room temperature ranges from $28-30^{\circ} \mathrm{C}$ in the Seed and Plant Breeding Laboratory, Faculty of Agriculture, University of Lampung in October 2017 to April 2018 The results showed that the combination treatment of Burangrang varieties with SP-36 $250 \mathrm{~kg} / \mathrm{h}$ a fertilizer stored without pepper powder or pepper powder was able to maintain its higher quality compared to other treatment combinations after being stored for up to six months
\end{abstract}

Key words: Fertilizer, pepper powder, soybean, storage, variety 


\section{PENDAHULUAN}

Kedelai (Glycine $\max$ L.) merupakan salah satu bahan pangan yang penting setelah beras. Kedelai mengandung kadar protein mencapai $40 \%$ dan banyak digunakan sebagai bahan utama untuk industri olahan seperti tahu, tempe, kecap dan susu. Kedelai juga merupakan bahan pangan yang sangat dibutuhkan oleh masyarakat Indonesia. Menurut Badan Pusat Statistik (2016), produktivitas kedelai pada tahun 2015 mencapai 15,69 ku/ha. Akan tetapi, seiring dengan permintaan konsumen yang meningkat tiap tahunnya, ketersediaan kedelai di Indonesia hanya dapat memenuhi $25-30 \%$ dari kebutuhan total. Selain itu, petani Indonesia kekurangan benih bermutu, benih kedelai bermutu hanya disediakan oleh pemerintah sebanyak $15 \%$ dari kebutuhan benih seluruhnya dan mengakibatkan terjadinya impor serta penggunaan benih hasil dari pertanaman sendiri dengan mutu benih yang tidak diketahui.

Benih kedelai merupakan benih yang cepat mengalami deteriorasi dalam masa penyimpanan. Proses deteriorasi benih berhubungan dengan perubahan biokimia dalam benih selama masa penyimpanan. Setiap varietas kedelai memiliki kandungan biokimia yang berbeda-beda akibat responsnya terhadap pemberian dosis pupuk yang berbeda. Perbedaan perilaku lot benih dapat ditunjukkan oleh tingkat viabilitas dan vigor pada benih kedelai yang disimpan. Lot benih merupakan sekumpulan benih yang dipanen pada waktu yang sama, lokasi yang sama, dan perlakuan yang sama. Dalam penelitian ini terdapat 15 lot benih yang berasal dari Periode I atau Periode Pembangunan Benih dalam konsep viabilitas benih yang menerapkan prinsip agronomik yaitu kombinasi antara varietas unggul (Anjasmoro, Burangrang, Grobogan) dan dosis SP-36 yang bertingkat dari 0 sampai $250 \mathrm{~kg} \mathrm{SP-36/ha.} \mathrm{Benih} \mathrm{kedelai}$ varietas berbeda yang dihasilkan dari tanaman yang diberi SP-36 dosis berbeda diduga memiliki mutu yang berbeda setelah melalui periode simpan 12 bulan. Penyimpanan benih kedelai pada suhu kamar, benih cepat mengalami kemunduran yang akan mengakibatkan kerusakan pada benih.

Penyimpanan menggunakan bubuk lada merupakan pemberian berupa bahan alami atau organik yang diharapkan dapat mempertahankan viabilitas namun tidak bersifat toksik bagi benih. Bubuk lada mengandung senyawa piperine memiliki banyak efek farmakologi antara lain sebagai antioksidan dan antimikrobial Antioksidan merupakan molekul yang dapat mencegah proses oksidasi molekul lain yang dapat menghasilkan radikal bebas dan memicu reaksi berantai yang dapat merusak sel. Antimikrobial merupakan senyawa yang dapat menghambat pertumbuhan atau dapat mematikan mikroba, sehingga penggunaan bubuk lada dalam proses penyimpanan dapat menunda terjadinya penurunan dan kerusakan pada benih (Evizal, 2013).

Tujuan penelitian ini adalah untuk mengetahui mutu benih terbaik dari limabelas lot benih kedelai yang berasal dari kombinasi 3 varietas dan 5 dosis pupuk SP36 yang disimpan sampai enam bulan menggunakan bubuk lada dan tanpa menggunakan bubuk lada

\section{METODE PENELITIAN}

\section{Tempat dan Waktu Penelitian}

Penelitian ini dilaksanakan pada bulan Oktober 2017 sampai dengan April 2018 di Laboratorium Benih dan Pemuliaan Tanaman Fakultas Pertanian Universitas Lampung.

\section{Metode Penelitian}

Penelitian ini terdiri dari dua percobaan secara terpisah dengan menggunakan Rancangan Acak Lengkap (RAL). Percobaan pertama yaitu penyimpanan benih kedelai dengan pemberian bubuk lada dan percobaan kedua yaitu penyimpanan benih kedelai tanpa 
pemberian bubuk lada. Penelitian ini terdiri dari kombinasi tiga varietas kedelai dan lima dosis pupuk SP-36 yang diulang sebanyak tiga kali. Kombinasi varietas dan dosis pupuk SP-36 pada penelitian ini adalah (1) Varietas Anjasmoro, dosis pupuk SP-36 0 $\mathrm{kg} / \mathrm{ha},(2)$ Varietas Anjasmoro, dosis pupuk SP-36 $100 \mathrm{~kg} / \mathrm{ha}$, (3) Varietas Anjasmoro, dosis pupuk SP-36 $150 \mathrm{~kg} / \mathrm{ha}$, (4) Varietas Anjasmoro, dosis pupuk SP-36 $200 \mathrm{~kg} / \mathrm{ha}$, (5) Varietas Anjasmoro, dosis pupuk SP-36 $250 \mathrm{~kg} / \mathrm{ha},(6)$ Varietas Grobogan, dosis pupuk SP-36 0 kg/ha, (7)Varietas Grobogan, dosis pupuk SP-36 $100 \mathrm{~kg} / \mathrm{ha}$, (8) Varietas Grobogan, dosis pupuk SP-36 $150 \mathrm{~kg} / \mathrm{ha}$, (9)Varietas Grobogan, dosis pupuk SP-36 $200 \mathrm{~kg} / \mathrm{ha}$, (10)Varietas Grobogan, dosis pupuk SP-36 $250 \mathrm{~kg} / \mathrm{ha}$, (11) Varietas Burangrang, dosis pupuk SP-36 $0 \mathrm{~kg} / \mathrm{ha}$, (12)Varietas Burangrang, dosis pupuk SP$36100 \mathrm{~kg} / \mathrm{ha}$, (13)Varietas Burangrang, dosis pupuk SP-36 $150 \mathrm{~kg} / \mathrm{ha}$, (14)Varietas Burangrang, dosis pupuk SP-36 $200 \mathrm{~kg} / \mathrm{ha}$, (15)Varietas Burangrang, dosis pupuk SP$36250 \mathrm{~kg} / \mathrm{ha}$. Setiap percobaan diulang tiga kali terdiri dari 45 satuan percobaan sehingga total satuan percobaan adalah 90 satuan percobaan. Data yang diperoleh dari penelitian ini homogenitas ragam antarperlakuan diuji dengan Uji Bartlett. Jika asumsi analisis ragam terpenuhi maka pemisahan nilai tengah perlakuan diuji dengan Uji BNJ (Beda Nyata Jujur) pada taraf $\alpha 5 \%$.

\section{Pelaksanaan Penelitian}

\section{Pengeringan Benih}

Benih hasil panen dari lahan percobaan dilakukan pengeringan hingga mencapai kadar air benih 8-9\%. Pengeringan dilakukan dengan menggunakan bantuan cahaya matahari. Pada proses ini dilakukan pemilahan dengan membuang kotoran benih seperti benih rusak, tanah, batu, dan ranting pohon yang tercampur pada saat panen.

\section{Persiapan Benih}

Hasil dari pemilahan benih dikemas ke dalam plastik klip dengan ziplock berukuran 20x12,5 cm pada tiap satuan percobaan. Tiap satuan percobaan berisi 600 butir benih yang telah dihitung menggunakan seed counter. Kemudian dimasukkan ke dalam kotak penyimpanan benih yang terbuat dari kayu berukuran 50x50x50 cm. Benih yang dibutuhkan dalam penelitian ini yaitu untuk pengujian kadar air (15 butir), pengujian persen kecambah benih ( 25 butir), pengujian kecepatan perkecambahan benih (25 butir) dan pengujian dengan tetrazolium (50 butir), total benih yang diperlukan yaitu 115 butir/satuan percobaan.

\section{Aplikasi Bubuk Lada}

Bubuk lada diberikan sebanyak 3 gram/100 gram benih ( Afandi, 2015). Pada percobaan yang menggunakan bubuk lada, bubuk lada yang diaplikasikan berbeda tergantung pada bobot benih pada tiap percobaan. Bubuk lada yang dibutuhkan untuk benih varietas Anjasmoro adalah 2,07 gram, varietas Grobogan 3,39 gram, dan varietas Burangrang 1,98 gram. Kemudian dibuat cetakan yang berfungsi untuk pengambilan bubuk lada sesuai dengan yang dibutuhkan. Bubuk lada diaplikasikan dengan cara dicampurkan secara merata ke dalam kantung plastik ziplock pada percobaan yang menggunakan bubuk lada. Sehingga didapatkan 45 satuan percobaan yang diberikan bubuk lada.

\section{Penyimpanan}

Benih yang telah dikemas dengan kantung plastik ziplock disimpan dalam ruang penyimpan dengan suhu kamar yaitu kisaran $28-30^{\circ} \mathrm{C}$. Lama penyimpanan yang dilakukan pada penelitian ini yaitu selama 6 bulan dari Oktober 2017 hingga April 2018.

\section{HASIL DAN PEMBAHASAN}

Hasil analisis ragam terhadap mutu limabelas lot benih kedelai yaitu kombinasi varietas dan dosis pupuk SP-36 setelah disimpan 6 bulan tanpa bubuk lada atau dengan penambahan bubuk lada ditampilkan 
Tabel 1. Rekapitulasi hasil analisis ragam terhadap limabelas lot benih kedelai kombinasi varietas dan dosis pupuk SP-36 berbeda pada semua variabel pengamatan pada penyimpanan menggunakan bubuk lada dan tidak menggunakan bubuk lada.

\begin{tabular}{|c|c|c|c|c|c|c|}
\hline \multirow{3}{*}{ Variabel Pengamatan } & \multicolumn{3}{|c|}{ Tanpa Bubuk Lada } & \multicolumn{3}{|c|}{ Menggunakan Bubuk Lada } \\
\hline & \multicolumn{3}{|c|}{ Bulan } & \multicolumn{3}{|c|}{ Bulan } \\
\hline & 2 & 4 & 6 & 2 & 4 & 6 \\
\hline Persentase kecambah & tn & tn & $*$ & tn & tn & $*$ \\
\hline $\begin{array}{l}\text { Kecepatan } \\
\text { perkecambahan }\end{array}$ & tn & tn & $*$ & tn & tn & $*$ \\
\hline Kadar air & $*$ & $*$ & $*$ & $*$ & $*$ & $*$ \\
\hline Indeks vigor & tn & tn & tn & tn & tn & tn \\
\hline $\begin{array}{l}\text { Bobot kering kecambah } \\
\text { normal }\end{array}$ & $*$ & $*$ & $*$ & $*$ & $*$ & $*$ \\
\hline
\end{tabular}

Keterangan : th = tidak berbeda pada $\alpha 5 \%$

$*$ = berbeda pada $\alpha 5 \%$

pada Tabel 1. Analisis ragam terhadap persentase perkecambahan, kadar air, kecepatan perkecambahan benih, indeks vigor, potensi tumbuh maksimum, bobot kering kecambah normal adalah variabelvariabel yang diamati mulai 2, 4, dan 6 bulan Kombinasi perlakuan varietas Burangrang dengan dosis pupuk SP-36 250 $\mathrm{kg} / \mathrm{ha}$ memiliki kemampuan yang lebih baik untuk mempertahankan viabilitas benih kedelai yang ditunjukkan dengan variabel pengamatan persentase berkecambah, kecepatan perkecambahan, kadar air, indeks vigor, dan potensi tumbuh maksimum. Hal ini disebabkan oleh penggunaan varietas tersebut diduga mempunyai kadar protein lebih rendah daripada varietas lainnya. Berdasarkan deskripsi, varietas Burangrang memiliki kandungan protein $39 \%$ sedangkan varietas Grobogan dan varietas Anjasmoto memiliki kandungan protein sebesar $43,9 \%$ dan 41,8 - 42,1\%. Semakin rendah kandungan protein, penurunan mutu benih akan semakin lama. Penelitian Kurnia (2017) menunjukkan benih yang memiliki cadangan makanan dan protein lebih banyak akan cepat mengalami kemunduran bila terjadi respirasi pada benih yang berhubungan dengan kadar air yang semakin tinggi.

Hasil pengukuran persen kadar air, kombinasi perlakuan varietas Burangrang dan dosis pupuk SP-36 $250 \mathrm{~kg} / \mathrm{ha}$ pada pengamatan bulan keempat dan keenam merupakan kombinasi perlakuan yang terbaik dalam menghasilkan mutu benih karena persen kadar air lebih rendah dibandingkan dengan kombinasi perlakuan lainnya. Menurut Kurnia (2017), semakin tinggi nilai kadar air maka semakin tinggi pula respirasi pada benih yang akan menyebabkan terjadi kemunduran benih yang cepat dalam masa penyimpanan.

Penggunaan varietas yang tepat dan dosis pemupukan SP-36 yang tinggi akan berpengaruh terhadap kandungan $\mathrm{P}$ di dalam benih. Menurut Copeland dan McDonald (2001), pupuk fosfor (P) merupakan salah satu penyusun senyawa fitin yang terkandung dalam benih. Timotiwu dan Nurmauli (1996), 
melaporkan peningkatkan produksi kedelai yang diberi pupuk TSP dan ZnSO4. Pupuk TSP merupakan sumber $P$ yang dapat meningkatkan bobot biji kedelai.

Menurut Bewley and Black (1994), senyawa fitin berfungsi sebagai sumber energi yang digunakan dalam masa perkecambahan. Hal ini sesuai dengan hasil yang ditunjukkan oleh kombinasi perlakuan Varietas Burangrang dan dosis pupuk SP-36 $250 \mathrm{~kg} / \mathrm{ha}$ pada penyimpanan bulan keenam masih menujukkan bahwa persen kecambah normal yang paling tinggi.

Benih kedelai merupakan benih yang cepat mengalami penurunan mutu akibat kandungan lemak yang cukup tinggi di dalam benih. Umumnya penurunan mutu benih kedelai akan terlihat pada bulan ketiga setelah penyimpanan. Pada penelitian ini benih yang disimpan berasal dari produksi benih yang dipupuk SP-36 dosis yang berbeda. Hasil yang diperoleh bahwa pemupukan SP-36 yang tinggi menunjukkan persen daya berkecambah, indeks vigor, dan potensi tumbuh maksimum yang lebih tinggi setelah benih tersebut disimpan 6 bulan. Diduga ini berkaitan dengan pernyataan Mugnisjah dan Setiawan (1990), unsur P dalam benih dapat meningkatkan vigor dan ketahanan simpan benih.

Kombinasi perlakuan Varietas Burangrang dan dosis pupuk SP-36 $250 \mathrm{~kg} / \mathrm{ha}$ juga memiliki persen kecepatan berkecambah yang paling tinggi dibandingkan dengan kombinasi lainnya yaitu 30,13\%. Variabel kecepatan berkecambah merupakan salah satu tolok ukur vigor benih. Menurut Sadjad (1993), tolok ukur kecepatan tumbuh mengindikasi vigor kekuatan tumbuh suatu benih karena benih yang cepat tumbuh lebih mampu menghadapi kondisi lapang yang suboptimum. Benih yang memiliki nilai kecepatan pertumbuhan lebih besar dari $30 \%$ per hari memiliki vigor kekuatan tumbuh yang kuat.

Berdasarkan variabel bobot kering kecambah normal, kombinasi perlakuan yang menggunakan varietas Grobogan memiliki bobot kering kecambah normal yang tertinggi. Hal ini disebabkan oleh perbedaan bobot benih masing-masing. Varietas Burangrang memiliki bobot tertinggi dibandingkan dengan varietas Anjasmoro dan varietas Burangrang. varietas Grobogan memiliki bobot 100 biji yaitu 18 gram sedangkan varietas Anjasmoro dan varietas Burangrang memiliki bobot 100 biji yaitu 14,8 - 15,3 gram dan 17 gram. Semakin tinggi bobot suatu benih, maka kecambah yang dihasilkan akan semakin besar yang mengakibatkan besarnya bobot kering kecambah normal.

\section{KESIMPULAN}

Kombinasi varietas dan dosis pupuk SP36 berpengaruh terhadap mutu benih kedelai. Mutu benih varietas Burangrang dengan dosis pupuk SP-36 $250 \mathrm{~kg} / \mathrm{ha}$ merupakan kombinasi terbaik berdasarkan variabel persentase kecambah, kecepatan perkecambahan, potensi tumbuh maksimum dan kadar air yang paling rendah pada penyimpanan sampai 6 bulan baik diberi maupun tidak diberi bubuk lada. 
Tabel 2. Pengaruh kombinasi varietas dan dosis pupuk SP-36 berbeda pada persentase kecambah benih kedelai yang disimpan menggunakan bubuk lada dan tanpa bubuk lada

\begin{tabular}{|c|c|c|c|c|c|c|}
\hline \multirow{3}{*}{ Perlakuan } & \multicolumn{3}{|c|}{ Tanpa Bubuk Lada } & \multicolumn{3}{|c|}{ Bubuk Lada } \\
\hline & \multicolumn{3}{|c|}{ Bulan } & \multicolumn{3}{|c|}{ Bulan } \\
\hline & 2 & 4 & 6 & 2 & 4 & 6 \\
\hline \multicolumn{7}{|c|}{ 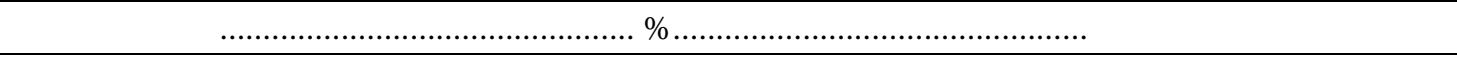 } \\
\hline Varietas Anjasmoro, SP-36 $0 \mathrm{~kg} / \mathrm{ha}$ & $96,0 \mathrm{a}$ & $85,3 \mathrm{a}$ & $72,0 \mathrm{ab}$ & $92,0 \mathrm{a}$ & $90,6 a$ & $70,6 \mathrm{ab}$ \\
\hline Varietas Anjasmoro, SP-36 100 kg/ha & $94,6 \mathrm{a}$ & $85,3 \mathrm{a}$ & $72,0 \mathrm{ab}$ & $92,0 \mathrm{a}$ & $82,6 \mathrm{a}$ & $73,3 \mathrm{ab}$ \\
\hline Varietas Anjasmoro, SP-36 150 kg/ha & $90,6 a$ & $72,0 \mathrm{a}$ & $66,6 \mathrm{ab}$ & $94,0 \mathrm{a}$ & $89,3 \mathrm{a}$ & $72,0 \mathrm{ab}$ \\
\hline Varietas Anjasmoro, SP-36 $200 \mathrm{~kg} / \mathrm{ha}$ & $90,6 \mathrm{a}$ & $62,6 \mathrm{a}$ & $60,0 \mathrm{ab}$ & $93,3 \mathrm{a}$ & $81,3 \mathrm{a}$ & $60,0 \mathrm{~b}$ \\
\hline Varietas Anjasmoro, SP-36 $250 \mathrm{~kg} / \mathrm{ha}$ & $84,0 \mathrm{a}$ & $82,6 \mathrm{a}$ & 80,0 a & $88,0 \mathrm{a}$ & $80,0 \mathrm{a}$ & $72,0 \mathrm{ab}$ \\
\hline Varietas Gerobogan, SP-36 $0 \mathrm{~kg} / \mathrm{ha}$ & $84,0 \mathrm{a}$ & $73,3 \mathrm{a}$ & 80,0 a & $88,0 \mathrm{a}$ & $76,0 \mathrm{a}$ & $74,6 \mathrm{ab}$ \\
\hline Varietas Gerobogan, SP-36 100 kg/ha & $94,6 \mathrm{a}$ & $69,3 \mathrm{a}$ & $69,3 \mathrm{ab}$ & $90,6 \mathrm{a}$ & $74,6 \mathrm{a}$ & $69,3 \mathrm{ab}$ \\
\hline Varietas Gerobogan, SP-36 150 kg/ha & $89,3 \mathrm{a}$ & $77,3 \mathrm{a}$ & $74,6 \mathrm{ab}$ & $89,3 \mathrm{a}$ & $78,6 \mathrm{a}$ & $65,3 \mathrm{ab}$ \\
\hline Varietas Gerobogan, SP-36 200 kg/ha & $86,6 \mathrm{a}$ & $81,3 \mathrm{a}$ & $64,0 \mathrm{ab}$ & $86,6 \mathrm{a}$ & $80,0 \mathrm{a}$ & $64,0 a b$ \\
\hline Varietas Gerobogan, SP-36 250 kg/ha & $89,3 \mathrm{a}$ & $78,6 \mathrm{a}$ & $70,6 \mathrm{ab}$ & $97,3 \mathrm{a}$ & $88,0 \mathrm{a}$ & $66,6 \mathrm{ab}$ \\
\hline Varietas Burangrang, SP-36 $0 \mathrm{~kg} / \mathrm{ha}$ & $85,3 \mathrm{a}$ & $80,0 \mathrm{a}$ & $77,3 \mathrm{ab}$ & $92,0 \mathrm{a}$ & $76,0 \mathrm{a}$ & $73,3 \mathrm{ab}$ \\
\hline Varietas Burangrang, SP-36 100 kg/ha & $92,0 \mathrm{a}$ & $84,0 \mathrm{a}$ & $74,6 \mathrm{ab}$ & $94,6 \mathrm{a}$ & $82,6 \mathrm{a}$ & $73,3 \mathrm{ab}$ \\
\hline Varietas Burangrang, SP-36 150 kg/ha & $96,0 \mathrm{a}$ & $86,6 a$ & $68,0 \mathrm{ab}$ & $92,0 \mathrm{a}$ & $90,6 a$ & $78,6 \mathrm{ab}$ \\
\hline Varietas Burangrang, SP-36 $200 \mathrm{~kg} / \mathrm{ha}$ & $97,3 \mathrm{a}$ & $77,3 \mathrm{a}$ & $58,6 \mathrm{~b}$ & $84,0 \mathrm{a}$ & $80,0 \mathrm{a}$ & $62,6 \mathrm{~b}$ \\
\hline Varietas Burangrang, SP-36 $250 \mathrm{~kg} / \mathrm{ha}$ & $92,0 \mathrm{a}$ & $81,3 \mathrm{a}$ & $80,0 \mathrm{a}$ & $98,6 \mathrm{a}$ & $92,0 \mathrm{a}$ & 84,0 a \\
\hline BNJ & - & - & 20,69 & - & - & 20,21 \\
\hline
\end{tabular}

Keterangan: Angka yang diikuti huruf yang sama pada kolom yang sama menunjukkan tidak berbeda pada uji BNJ taraf 5\%. 
Tabel 3. Pengaruh kombinasi varietas dan dosis pupuk SP-36 berbeda pada kecepatan perkecambahan benih kedelai yang disimpan menggunakan bubuk lada dan tanpa bubuk lada

\begin{tabular}{|c|c|c|c|c|c|c|}
\hline \multirow{3}{*}{ Perlakuan } & \multicolumn{3}{|c|}{ Tanpa Bubuk Lada } & \multicolumn{3}{|c|}{ Bubuk Lada } \\
\hline & \multicolumn{3}{|c|}{ Bulan } & \multicolumn{3}{|c|}{ Bulan } \\
\hline & 2 & 4 & 6 & 2 & 4 & 6 \\
\hline & $\%$. & & & & & \\
\hline Varietas Anjasmoro, SP-36 $0 \mathrm{~kg} / \mathrm{ha}$ & $44,89 \mathrm{a}$ & $33,71 \mathrm{a}$ & $25,42 \mathrm{ab}$ & $45,22 \mathrm{a}$ & $35,38 \mathrm{a}$ & $25,46 a b$ \\
\hline Varietas Anjasmoro, SP-36 100 kg/ha & $43,24 a$ & $30,44 a$ & $21,42 \mathrm{abc}$ & $44,04 \mathrm{a}$ & $30,47 \mathrm{a}$ & $24,19 b$ \\
\hline Varietas Anjasmoro, SP-36 $150 \mathrm{~kg} / \mathrm{ha}$ & $42,93 a$ & $32,44 a$ & $26,13 \mathrm{ab}$ & $42,13 \mathrm{a}$ & $36,87 \mathrm{a}$ & $24,96 \mathrm{ab}$ \\
\hline Varietas Anjasmoro, SP-36 200 kg/ha & $45,20 \mathrm{a}$ & $30,27 \mathrm{a}$ & $17,04 \mathrm{c}$ & $45,78 \mathrm{a}$ & $34,00 \mathrm{a}$ & $16,44 \mathrm{c}$ \\
\hline Varietas Anjasmoro, SP-36 $250 \mathrm{~kg} / \mathrm{ha}$ & $46,89 \mathrm{a}$ & $32,93 \mathrm{a}$ & $22,70 \mathrm{abc}$ & $44,71 \mathrm{a}$ & $35,98 \mathrm{a}$ & $24,47 b$ \\
\hline Varietas Gerobogan, SP-36 $0 \mathrm{~kg} / \mathrm{ha}$ & $43,11 \mathrm{a}$ & $31,29 \mathrm{a}$ & $27,78 \mathrm{ab}$ & $43,11 \mathrm{a}$ & $30,27 \mathrm{a}$ & $28,36 a b$ \\
\hline Varietas Gerobogan, SP-36 100 kg/ha & $45,78 \mathrm{a}$ & $30,62 \mathrm{a}$ & $26,58 \mathrm{ab}$ & $41,93 a$ & $31,27 \mathrm{a}$ & $20,69 b c$ \\
\hline Varietas Gerobogan, SP-36 150 kg/ha & $40,78 \mathrm{a}$ & $28,80 \mathrm{a}$ & $25,49 \mathrm{ab}$ & $44,27 \mathrm{a}$ & $32,11 \mathrm{a}$ & $25,61 \mathrm{ab}$ \\
\hline Varietas Gerobogan, SP-36 200 kg/ha & $43,24 a$ & $32,44 a$ & $19,69 \mathrm{bc}$ & $43,04 \mathrm{a}$ & $32,16 a$ & $26,82 \mathrm{ab}$ \\
\hline Varietas Gerobogan, SP-36 $250 \mathrm{~kg} / \mathrm{ha}$ & $43,58 \mathrm{a}$ & $35,51 \mathrm{a}$ & $22,42 \mathrm{abc}$ & $46,33 \mathrm{a}$ & $35,60 \mathrm{a}$ & $26,91 \mathrm{ab}$ \\
\hline Varietas Burangrang, SP-36 0 kg/ha & $42,38 \mathrm{a}$ & $34,89 a$ & $24,40 \mathrm{abc}$ & $43,11 \mathrm{a}$ & $35,82 \mathrm{a}$ & $24,67 b$ \\
\hline Varietas Burangrang, SP-36 100 kg/ha & $45,60 \mathrm{a}$ & $36,22 \mathrm{a}$ & $28,33 \mathrm{a}$ & $43,56 a$ & $34,78 \mathrm{a}$ & $27,04 \mathrm{ab}$ \\
\hline Varietas Burangrang, SP-36 $150 \mathrm{~kg} / \mathrm{ha}$ & $45,78 \mathrm{a}$ & $36,40 \mathrm{a}$ & $25,16 a b c$ & $44,87 \mathrm{a}$ & $36,09 \mathrm{a}$ & $30,53 a$ \\
\hline Varietas Burangrang, SP-36 $200 \mathrm{~kg} / \mathrm{ha}$ & $44,11 \mathrm{a}$ & $32,98 \mathrm{a}$ & $22,40 \mathrm{abc}$ & $45,89 \mathrm{a}$ & $31,53 \mathrm{a}$ & $23,76 b$ \\
\hline Varietas Burangrang, SP-36 $250 \mathrm{~kg} / \mathrm{ha}$ & $47,33 a$ & $38,89 a$ & $30,13 \mathrm{a}$ & $48,56 a$ & $38,89 \mathrm{a}$ & $30,64 a$ \\
\hline 8,33 & - & 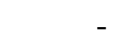 & 5,81 & & & \\
\hline
\end{tabular}

Keterangan: Angka yang diikuti huruf yang sama pada kolom yang sama menunjukkan tidak berbeda pada uji BNJ taraf $5 \%$. 
Tabel 4. Pengaruh kombinasi varietas dan dosis pupuk SP-36 berbeda pada persentase kadar air benih kedelai yang disimpan menggunakan bubuk lada dan tanpa bubuk lada

\begin{tabular}{|c|c|c|c|c|c|c|}
\hline \multirow{3}{*}{ Perlakuan } & \multicolumn{3}{|c|}{ Tanpa Bubuk Lada } & \multicolumn{3}{|c|}{ Bubuk Lada } \\
\hline & \multicolumn{3}{|c|}{ Bulan } & \multicolumn{3}{|c|}{ Bulan } \\
\hline & 2 & 4 & 6 & 2 & 4 & 6 \\
\hline \multicolumn{7}{|c|}{ 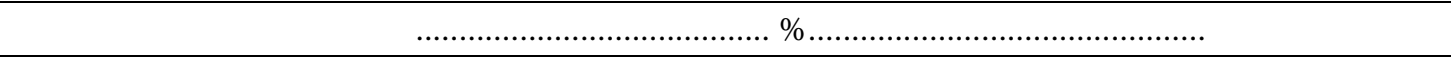 } \\
\hline Varietas Anjasmoro, SP-36 $0 \mathrm{~kg} / \mathrm{ha}$ & $8,6 \mathrm{ab}$ & $10,5 \mathrm{bc}$ & $10,5 \mathrm{ab}$ & $8,9 \mathrm{bc}$ & $10,2 \mathrm{bc}$ & $10,2 \mathrm{ab}$ \\
\hline Varietas Anjasmoro, SP-36 100 kg/ha & $8,6 \mathrm{ab}$ & $9,7 \mathrm{ab}$ & $10,2 \mathrm{ab}$ & $8,4 \mathrm{a}$ & $9,7 \mathrm{ab}$ & $10,1 \mathrm{a}$ \\
\hline Varietas Anjasmoro, SP-36 $150 \mathrm{~kg} / \mathrm{ha}$ & $8,8 \mathrm{ab}$ & $9,8 \mathrm{ab}$ & $10,0 \mathrm{ab}$ & $8,7 \mathrm{ab}$ & $9,8 \mathrm{ab}$ & $10,2 \mathrm{ab}$ \\
\hline Varietas Anjasmoro, SP-36 200 kg/ha & $9,5 b$ & $10,7 \mathrm{c}$ & $10,7 b$ & $9,7 \mathrm{c}$ & $10,7 \mathrm{c}$ & $10,9 \mathrm{~b}$ \\
\hline Varietas Anjasmoro, SP-36 250 kg/ha & $9,1 \mathrm{~b}$ & $9,9 b$ & $10,0 \mathrm{ab}$ & $9,1 b$ & $9,9 \mathrm{~b}$ & $10,2 \mathrm{ab}$ \\
\hline Varietas Gerobogan, SP-36 0 kg/ha & $9,0 \mathrm{~b}$ & $9,5 \mathrm{ab}$ & $10,4 \mathrm{ab}$ & $8,7 \mathrm{ab}$ & $9,5 \mathrm{ab}$ & $10,2 \mathrm{ab}$ \\
\hline Varietas Gerobogan, SP-36 100 kg/ha & $9,1 b$ & $10,4 b c$ & $11,0 \mathrm{~b}$ & $9,2 b$ & $10,4 b c$ & $10,7 \mathrm{~b}$ \\
\hline Varietas Gerobogan, SP-36 $150 \mathrm{~kg} / \mathrm{ha}$ & $8,7 \mathrm{ab}$ & $9,9 b$ & $10,6 b$ & $8,9 \mathrm{ab}$ & $9,9 \mathrm{~b}$ & $10,5 \mathrm{ab}$ \\
\hline Varietas Gerobogan, SP-36 200 kg/ha & $8,8 \mathrm{ab}$ & $9,9 \mathrm{~b}$ & $10,6 b$ & $8,8 \mathrm{ab}$ & $9,9 \mathrm{~b}$ & $10,4 \mathrm{ab}$ \\
\hline Varietas Gerobogan, SP-36 250 kg/ha & $9,3 b$ & $10,5 b c$ & $10,8 b$ & $9,3 \mathrm{bc}$ & $10,5 \mathrm{bc}$ & $10,6 \mathrm{ab}$ \\
\hline Varietas Burangrang, SP-36 0 kg/ha & $8,8 \mathrm{ab}$ & $9,9 \mathrm{~b}$ & $10,4 \mathrm{ab}$ & $8,9 \mathrm{ab}$ & $9,9 \mathrm{~b}$ & $10,7 \mathrm{~b}$ \\
\hline Varietas Burangrang, SP-36 100 kg/ha & $8,8 \mathrm{ab}$ & $9,9 b$ & $10,5 b$ & $8,7 \mathrm{ab}$ & $9,9 \mathrm{~b}$ & $10,5 \mathrm{ab}$ \\
\hline Varietas Burangrang, SP-36 $150 \mathrm{~kg} / \mathrm{ha}$ & $8,3 \mathrm{a}$ & $9,6 \mathrm{ab}$ & $10,0 \mathrm{ab}$ & $8,4 \mathrm{a}$ & $9,6 \mathrm{ab}$ & $10,0 \mathrm{a}$ \\
\hline Varietas Burangrang, SP-36 $200 \mathrm{~kg} / \mathrm{ha}$ & $8,9 \mathrm{ab}$ & $10,3 \mathrm{bc}$ & $10,8 b$ & $9,2 b$ & $10,3 \mathrm{bc}$ & $10,6 \mathrm{ab}$ \\
\hline Varietas Burangrang, SP-36 $250 \mathrm{~kg} / \mathrm{ha}$ & $8,4 \mathrm{ab}$ & $9,2 \mathrm{a}$ & $9,9 \mathrm{a}$ & $8,5 \mathrm{ab}$ & $9,2 \mathrm{a}$ & $10,1 \mathrm{a}$ \\
\hline $\mathrm{BNJ}$ & 0,470 & & & & & \\
\hline
\end{tabular}

Keterangan: Angka yang diikuti huruf yang sama pada kolom yang sama menunjukkan tidak berbeda pada uji BNJ taraf $5 \%$. 
Kurniati et al: Pengaruh Penyimpanan Sampai Enam Bulan Menggunakan Bubuk dan Tanpa Bubuk ... Jurnal Agrotropika Vol. 19 No. 1, Mei 2020:11-21

Tabel 5. Pengaruh kombinasi varietas dan dosis pupuk SP-36 berbeda pada persentase indeks vigor benih kedelai yang disimpan menggunakan bubuk lada dan tanpa bubuk lada

\begin{tabular}{|c|c|c|c|c|c|c|}
\hline \multirow{3}{*}{ Perlakuan } & \multicolumn{3}{|c|}{ Tanpa Bubuk Lada } & \multicolumn{3}{|c|}{ Bubuk Lada } \\
\hline & \multicolumn{3}{|c|}{ Bulan } & \multicolumn{3}{|c|}{ Bulan } \\
\hline & 2 & 4 & 6 & 2 & 4 & 6 \\
\hline & & $\%$ & . & . & & \\
\hline Varietas Anjasmoro, SP-36 $0 \mathrm{~kg} / \mathrm{ha}$ & $96,00 \mathrm{a}$ & $80,00 \mathrm{a}$ & $65,33 \mathrm{ab}$ & $92,00 \mathrm{a}$ & $84,00 \mathrm{a}$ & $64,00 \mathrm{a}$ \\
\hline Varietas Anjasmoro, SP-36 100 kg/ha & $94,67 \mathrm{a}$ & $80,00 \mathrm{a}$ & $62,67 \mathrm{ab}$ & $92,00 \mathrm{a}$ & $82,67 \mathrm{a}$ & $69,33 \mathrm{a}$ \\
\hline Varietas Anjasmoro, SP-36 150 kg/ha & $90,67 \mathrm{a}$ & $72,00 \mathrm{a}$ & $64,00 \mathrm{ab}$ & $96,00 \mathrm{a}$ & $85,33 \mathrm{a}$ & $70,67 \mathrm{a}$ \\
\hline Varietas Anjasmoro, SP-36 200 kg/ha & $90,67 \mathrm{a}$ & $62,67 a$ & $50,67 b$ & $92,00 \mathrm{a}$ & $77,33 \mathrm{a}$ & $57,33 \mathrm{a}$ \\
\hline Varietas Anjasmoro, SP-36 $250 \mathrm{~kg} / \mathrm{ha}$ & $84,00 \mathrm{a}$ & $78,67 \mathrm{a}$ & $73,33 \mathrm{ab}$ & $88,00 \mathrm{a}$ & $77,33 a$ & $68,00 \mathrm{a}$ \\
\hline Varietas Gerobogan, SP-36 $0 \mathrm{~kg} / \mathrm{ha}$ & $84,00 \mathrm{a}$ & $73,33 a$ & $73,33 \mathrm{ab}$ & $88,00 \mathrm{a}$ & $70,67 \mathrm{a}$ & $68,00 \mathrm{a}$ \\
\hline Varietas Gerobogan, SP-36 100 kg/ha & $94,67 \mathrm{a}$ & $69,33 \mathrm{a}$ & $61,33 \mathrm{ab}$ & $90,67 \mathrm{a}$ & $68,00 \mathrm{a}$ & $66,67 \mathrm{a}$ \\
\hline Varietas Gerobogan, SP-36 150 kg/ha & $89,33 \mathrm{a}$ & $72,00 \mathrm{a}$ & $64,00 \mathrm{ab}$ & $88,00 \mathrm{a}$ & $77,33 \mathrm{a}$ & $61,33 \mathrm{a}$ \\
\hline Varietas Gerobogan, SP-36 200 kg/ha & $86,67 \mathrm{a}$ & $77,33 a$ & $53,33 \mathrm{ab}$ & $86,67 \mathrm{a}$ & $69,33 a$ & $62,67 \mathrm{a}$ \\
\hline Varietas Gerobogan, SP-36 250 kg/ha & $89,33 a$ & $76,00 \mathrm{a}$ & $64,00 \mathrm{ab}$ & $97,33 \mathrm{a}$ & $80,00 \mathrm{a}$ & $65,33 \mathrm{a}$ \\
\hline Varietas Burangrang, SP-36 $0 \mathrm{~kg} / \mathrm{ha}$ & $85,33 \mathrm{a}$ & $77,33 \mathrm{a}$ & $70,67 \mathrm{ab}$ & $92,00 \mathrm{a}$ & $72,00 \mathrm{a}$ & $72,00 \mathrm{a}$ \\
\hline Varietas Burangrang, SP-36 100 kg/ha & $92,00 \mathrm{a}$ & $80,00 \mathrm{a}$ & $69,33 \mathrm{ab}$ & $94,67 \mathrm{a}$ & $80,00 \mathrm{a}$ & $70,67 \mathrm{a}$ \\
\hline Varietas Burangrang, SP-36 150 kg/ha & $96,00 \mathrm{a}$ & $82,67 \mathrm{a}$ & $65,33 \mathrm{ab}$ & $92,00 \mathrm{a}$ & $85,33 \mathrm{a}$ & $73,33 \mathrm{a}$ \\
\hline Varietas Burangrang, SP-36 $200 \mathrm{~kg} / \mathrm{ha}$ & $97,33 a$ & $74,67 \mathrm{a}$ & $58,67 \mathrm{ab}$ & $84,00 \mathrm{a}$ & $78,67 \mathrm{a}$ & $68,00 \mathrm{a}$ \\
\hline Varietas Burangrang, SP-36 $250 \mathrm{~kg} / \mathrm{ha}$ & $92,00 \mathrm{a}$ & $77,33 \mathrm{a}$ & $74,67 \mathrm{a}$ & $98,67 \mathrm{a}$ & $85,33 \mathrm{a}$ & $80,00 \mathrm{a}$ \\
\hline
\end{tabular}

Keterangan: Angka yang diikuti huruf yang sama pada kolom yang sama menunjukkan tidak berbeda pada uji BNJ taraf $5 \%$. 
Kurniati et al: Pengaruh Penyimpanan Sampai Enam Bulan Menggunakan Bubuk dan Tanpa Bubuk ... Jurnal Agrotropika Vol. 19 No. 1, Mei 2020:11-21

Tabel 6. Pengaruh kombinasi varietas dan dosis pupuk SP-36 berbeda pada persentase potensi tumbuh maksimum benih kedelai yang disimpan menggunakan bubuk lada dan tanpa bubuk lada.

\begin{tabular}{|c|c|c|c|c|c|c|}
\hline \multirow{3}{*}{ Perlakuan } & \multicolumn{3}{|c|}{ Tanpa bubuk Lada } & \multicolumn{3}{|c|}{ Bubuk Lada } \\
\hline & \multicolumn{3}{|c|}{ Bulan } & \multicolumn{3}{|c|}{ Bulan } \\
\hline & 2 & 4 & 6 & 2 & 4 & 6 \\
\hline & & & & $\ldots$ & & \\
\hline Varietas Anjasmoro, SP-36 $0 \mathrm{~kg} / \mathrm{ha}$ & $98,67 \mathrm{a}$ & $93,33 \mathrm{a}$ & $92,00 \mathrm{ab}$ & $96,00 \mathrm{a}$ & $94,67 \mathrm{a}$ & $90,67 \mathrm{a}$ \\
\hline Varietas Anjasmoro, SP-36 100 kg/ha & $98,67 \mathrm{a}$ & $90,67 \mathrm{ab}$ & $90,67 \mathrm{ab}$ & $93,33 a$ & $85,33 a$ & $90,67 \mathrm{a}$ \\
\hline Varietas Anjasmoro, SP-36 $150 \mathrm{~kg} / \mathrm{ha}$ & $94,67 \mathrm{a}$ & $82,67 \mathrm{ab}$ & $90,67 \mathrm{ab}$ & $97,33 a$ & $96,00 \mathrm{a}$ & $89,33 a$ \\
\hline Varietas Anjasmoro, SP-36 $200 \mathrm{~kg} / \mathrm{ha}$ & $90,67 \mathrm{a}$ & $70,67 \mathrm{~b}$ & $77,33 \mathrm{~b}$ & $97,33 \mathrm{a}$ & $85,33 \mathrm{a}$ & $84,00 \mathrm{a}$ \\
\hline Varietas Anjasmoro, SP-36 $250 \mathrm{~kg} / \mathrm{ha}$ & $94,67 \mathrm{a}$ & $86,67 \mathrm{ab}$ & $96,00 \mathrm{ab}$ & $97,33 a$ & $86,67 \mathrm{a}$ & $88,00 \mathrm{a}$ \\
\hline Varietas Gerobogan, SP-36 $0 \mathrm{~kg} / \mathrm{ha}$ & $96,00 \mathrm{a}$ & $98,67 \mathrm{a}$ & $98,67 \mathrm{a}$ & $97,33 a$ & $96,00 \mathrm{a}$ & $90,67 \mathrm{a}$ \\
\hline Varietas Gerobogan, SP-36 100 kg/ha & $97,33 \mathrm{a}$ & $92,00 \mathrm{ab}$ & $93,33 \mathrm{ab}$ & $98,67 \mathrm{a}$ & $86,67 \mathrm{a}$ & $93,33 \mathrm{a}$ \\
\hline Varietas Gerobogan, SP-36 $150 \mathrm{~kg} / \mathrm{ha}$ & $94,67 \mathrm{a}$ & 93,33 a & $92,00 \mathrm{ab}$ & $93,33 a$ & $93,33 \mathrm{a}$ & $82,67 \mathrm{a}$ \\
\hline Varietas Gerobogan, SP-36 $200 \mathrm{~kg} / \mathrm{ha}$ & $96,00 \mathrm{a}$ & $94,67 \mathrm{a}$ & $93,33 \mathrm{ab}$ & $98,67 \mathrm{a}$ & $94,67 \mathrm{a}$ & $97,33 \mathrm{a}$ \\
\hline Varietas Gerobogan, SP-36 $250 \mathrm{~kg} / \mathrm{ha}$ & $98,67 \mathrm{a}$ & $94,67 \mathrm{a}$ & $94,67 \mathrm{ab}$ & $96,00 \mathrm{a}$ & $97,33 \mathrm{a}$ & $88,00 \mathrm{a}$ \\
\hline Varietas Burangrang, SP-36 $0 \mathrm{~kg} / \mathrm{ha}$ & $93,33 \mathrm{a}$ & $89,33 \mathrm{ab}$ & $92,00 \mathrm{ab}$ & $93,33 \mathrm{a}$ & $85,33 \mathrm{a}$ & $96,00 \mathrm{a}$ \\
\hline Varietas Burangrang, SP-36 100 kg/ha & $97,33 \mathrm{a}$ & 93,33 a & $92,00 \mathrm{ab}$ & $93,33 a$ & $96,00 \mathrm{a}$ & $92,00 \mathrm{a}$ \\
\hline Varietas Burangrang, SP-36 $150 \mathrm{~kg} / \mathrm{ha}$ & $97,33 \mathrm{a}$ & $96,00 \mathrm{a}$ & $89,33 \mathrm{ab}$ & $93,33 a$ & $97,33 a$ & $94,67 \mathrm{a}$ \\
\hline Varietas Burangrang, SP-36 200 kg/ha & $98,67 \mathrm{a}$ & $88,00 \mathrm{ab}$ & $88,00 \mathrm{ab}$ & $88,00 \mathrm{a}$ & $85,33 a$ & $88,00 \mathrm{a}$ \\
\hline Varietas Burangrang, SP-36 $250 \mathrm{~kg} / \mathrm{ha}$ & $96,00 \mathrm{a}$ & $94,67 \mathrm{a}$ & $97,33 \mathrm{a}$ & $97,33 a$ & $94,67 \mathrm{a}$ & $97,33 a$ \\
\hline
\end{tabular}

Keterangan: Angka yang diikuti huruf yang sama pada kolom yang sama menunjukkan tidak berbeda pada uji BNJ taraf $5 \%$. 
Kurniati et al: Pengaruh Penyimpanan Sampai Enam Bulan Menggunakan Bubuk dan Tanpa Bubuk ... Jurnal Agrotropika Vol. 19 No. 1, Mei 2020:11-21

Tabel 7. Pengaruh kombinasi varietas dan dosis pupuk SP-36 berbeda pada bobot kering kecambah normal kedelai yang disimpan menggunakan bubuk lada dan tanpa bubuk lada.

\begin{tabular}{|c|c|c|c|c|c|c|}
\hline \multirow{3}{*}{ Perlakuan } & \multicolumn{3}{|c|}{ Tanpa Bubuk Lada } & \multicolumn{3}{|c|}{ Bubuk Lada } \\
\hline & \multicolumn{3}{|c|}{ Bulan } & \multicolumn{3}{|c|}{ Bulan } \\
\hline & 2 & 4 & 6 & 2 & 4 & 6 \\
\hline \multicolumn{7}{|c|}{ 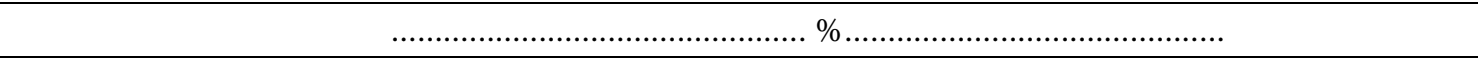 } \\
\hline Varietas Anjasmoro, SP-36 0 kg/ha & $0,025 \mathrm{bc}$ & $0,025 b$ & $0,029 b$ & $0,024 \mathrm{bc}$ & $0,027 \mathrm{bc}$ & $0,026 b$ \\
\hline Varietas Anjasmoro, SP-36 $100 \mathrm{~kg} / \mathrm{ha}$ & $0,027 \mathrm{bc}$ & $0,021 b c$ & $0,030 \mathrm{~b}$ & $0,026 \mathrm{bc}$ & $0,026 b c$ & $0,028 b$ \\
\hline Varietas Anjasmoro, SP-36 $150 \mathrm{~kg} / \mathrm{ha}$ & $0,028 \mathrm{bc}$ & $0,022 b c$ & $0,030 b$ & $0,029 b c$ & $0,024 b c$ & $0,027 \mathrm{~b}$ \\
\hline Varietas Anjasmoro, SP-36 $200 \mathrm{~kg} / \mathrm{ha}$ & $0,026 b c$ & $0,017 \mathrm{bc}$ & $0,026 b$ & $0,030 \mathrm{bc}$ & $0,023 b c$ & $0,025 b$ \\
\hline Varietas Anjasmoro, SP-36 250 kg/ha & $0,025 \mathrm{bc}$ & $0,024 b$ & $0,031 b$ & $0,029 b c$ & $0,021 b c$ & $0,029 b$ \\
\hline Varietas Gerobogan, SP-36 0 kg/ha & $0,039 a$ & $0,035 \mathrm{a}$ & $0,040 \mathrm{a}$ & $0,032 \mathrm{a}$ & $0,032 \mathrm{a}$ & $0,039 \mathrm{a}$ \\
\hline Varietas Gerobogan, SP-36 100 kg/ha & $0,038 \mathrm{a}$ & $0,034 \mathrm{a}$ & $0,040 \mathrm{a}$ & $0,038 \mathrm{a}$ & $0,033 \mathrm{a}$ & $0,039 \mathrm{a}$ \\
\hline Varietas Gerobogan, SP-36 150 kg/ha & $0,035 \mathrm{a}$ & $0,035 \mathrm{a}$ & $0,038 \mathrm{ab}$ & $0,034 \mathrm{a}$ & $0,034 \mathrm{a}$ & $0,039 \mathrm{a}$ \\
\hline Varietas Gerobogan , SP-36 200 kg/ha & $0,035 \mathrm{a}$ & $0,035 \mathrm{a}$ & $0,048 \mathrm{a}$ & $0,036 a$ & $0,033 \mathrm{a}$ & $0,041 \mathrm{a}$ \\
\hline Varietas Gerobogan , SP-36 250 kg/ha & $0,036 \mathrm{a}$ & $0,035 \mathrm{a}$ & $0,039 \mathrm{a}$ & $0,036 \mathrm{a}$ & $0,038 \mathrm{a}$ & $0,043 \mathrm{a}$ \\
\hline Varietas Burangrang, SP-36 $0 \mathrm{~kg} / \mathrm{ha}$ & $0,032 b$ & $0,025 b$ & $0,034 b$ & $0,030 \mathrm{bc}$ & $0,027 b c$ & $0,030 \mathrm{~b}$ \\
\hline Varietas Burangrang, SP-36 100 kg/ha & $0,031 b$ & $0,028 b$ & $0,031 b$ & $0,033 \mathrm{a}$ & $0,028 b c$ & $0,030 \mathrm{~b}$ \\
\hline Varietas Burangrang, SP-36 150 kg/ha & $0,030 \mathrm{~b}$ & $0,028 b$ & $0,033 b$ & $0,028 \mathrm{bc}$ & $0,025 \mathrm{bc}$ & $0,030 \mathrm{~b}$ \\
\hline Varietas Burangrang, SP-36 200 kg/ha & $0,030 \mathrm{~b}$ & $0,026 b$ & $0,034 b$ & $0,029 b c$ & $0,027 b c$ & $0,033 \mathrm{ab}$ \\
\hline Varietas Burangrang, SP-36 $250 \mathrm{~kg} / \mathrm{ha}$ & $0,032 b$ & $0,028 \mathrm{~b}$ & $0,033 b$ & $0,033 \mathrm{a}$ & $0,028 b$ & $0,031 b$ \\
\hline $\mathrm{BNJ}$ & 0,005 & 07 & 10 & & & 08 \\
\hline
\end{tabular}

Keterangan:Angka yang diikuti huruf yang sama pada kolom yang sama menunjukkan tidak berbeda pada uji BNJ taraf 5\%.

\section{DAFTAR PUSTAKA}

Afandi, A. 2015. Keefektifan Campuran Serbuk Pala dan Lada Hitam Terhadap Mortalitas Sitophilus orizae di Penyimpanan. Skripsi. Universitas Syiah Kuala. Banda Aceh. 57 p.

Badan Pusat Statistik (BPS). 2016. Produksi Padi, Jagung, dan Kedelai 2016. http://bps.go.id. Diakses pada 27 Februari 2018.

Bewley, J.D. and M. Black. 1994. Seed: Physiology of Develpoment and Germination. Second edition. London \& New York. Plenum Press.

Copeland, L.O. and M.B. McDonald. 2001. Principal of Seed Science and Technology. 3 th. Ed. McMillan PubliCo., New York. 166 p.

Evizal, R. 2013. Tanaman Rempah dan Fitofarmaka. Lembaga Penelitian Universitas Lampung. Bandar Lampung. 197 p.
ISTA. 2010. International Rules for Seed Testing. ISTA. Switzerland.

Kurnia, P. 2017. Pengaruh Lama Simpan Terhadap Mutu Benih Kedelai. Jurnal Penelitian. Politeknik Negeri Jember, 1(1) :5-9.

Mugnisjah, W.Q. dan A. Setiawan. 1990. Pengantar Produksi Benih. PT Raja Grafindo Persada. Jakarta. $204 \mathrm{hlm}$.

Sadjad, S. 1993. Dari Benih Kepada Benih. PT. Gramedia Widiasarna Indonesia. Jakarta. $144 \mathrm{p}$.

Timotiwu, P. B. dan N. Nurmauli. 1996. Kombinasi Pupuk TSP dan ZnSO4 Untuk Meningkatkan Produksi Kedelai di Lampung. Jurnal Agrotropika, 1(1): 1115. 